\title{
Nerve Tissue
}

National Cancer Institute

\section{Source}

National Cancer Institute. Nerve Tissue. NCI Thesaurus. Code C13052.

The tissue that generates and conducts electrical signals in the body. It contains the neurons. 